\title{
Selenium (Se) Regulates Seedling Growth in Wheat under Drought Stress
}

\author{
Fahim Nawaz, ${ }^{1}$ Muhammad Yasin Ashraf, ${ }^{2}$ Rashid Ahmad, \\ Ejaz Ahmad Waraich, ${ }^{1}$ and Rana Nauman Shabbir ${ }^{1}$ \\ ${ }^{1}$ Department of Crop Physiology, University of Agriculture, Faisalabad 38040, Pakistan \\ ${ }^{2}$ Nuclear Institute for Agriculture and Biology (NIAB), P.O. Box No. 128, Faisalabad, Pakistan \\ Correspondence should be addressed to Fahim Nawaz; fahim5382@gmail.com
}

Received 19 April 2014; Revised 6 July 2014; Accepted 9 July 2014; Published 22 July 2014

Academic Editor: Wen-Chi Hou

Copyright (C) 2014 Fahim Nawaz et al. This is an open access article distributed under the Creative Commons Attribution License, which permits unrestricted use, distribution, and reproduction in any medium, provided the original work is properly cited.

Selenium (Se) is an essential micronutrient with a range of physiological and antioxidative properties. Reports regarding effect of Se application on plants growth and development are not consistent. The identification of effective Se dose and application method is crucial for better understanding of Se translocation within crop plants under drought stress. The present study aimed at investigating the role of Se supplementation in improving the drought tolerance potential of wheat at early growth stages. Two wheat genotypes (Kohistan-97 and Pasban-90) were grown in plastic pots $(8 \times 12 \mathrm{~cm})$ in green/wire-house experiments. Results demonstrated that the growth and biomass of seedlings increased at high Se foliar concentrations and decreased at low and high Se fertigation levels. The seedlings exhibited the highest values for plant height stress tolerance index (PHSI), root length stress tolerance index (RLSI), dry matter stress tolerance index (DMSI), and fresh matter stress tolerance indices (FMSI) at Se fertigation level of $7.35 \mu \mathrm{M}$, whereas Se foliar treatment of $7.06 \mu \mathrm{M}$ resulted in maximum values for these indices. The seedlings foliarly sprayed with Se maintained higher DMSI and FMSI than those fertigated with Se which suggests that Se foliar spray is more effective than Se fertigation for improving drought tolerance.

\section{Introduction}

Drought stress has emerged as the single most critical threat to world food security. It seriously limits agricultural productivity, especially in areas where rainfall is limiting or unreliable, so improving yield under limited water conditions has become a crucial target for arid and semiarid regions of the world [1-3]. Exposure to drought stress poses serious challenges for the survival of plants, because it results in impaired germination and seedling growth [4] and affects many growth variables of the plant $[5,6]$, thus reducing fitness and harvestable yield of plants [3].

The physiological and antioxidant properties of selenium (Se) have increased the curiosity of many biologists in recent past. Although it does not take part in various vital metabolic processes in plants, it may help to reduce the damage under physiological stresses $[7,8]$. Recently, Se has been reported to counteract the detrimental effects of various environmental stresses such as heavy metals [9], UV-B [10, 11], excess water [12], salt [13], cold [14], high temperature [15], senescence [16], and desiccation [17]. However, reports on the role of Se in plants under water stress conditions are scanty. It may regulate water status [18] and increase biomass production [19] by the activation of antioxidant apparatus of water stressed plants [20,21].

Numerous strategies, namely, seed dressing/coating [22], seed soaking [19], soil application [23], and foliar spray [24], have been used to supply Se in plants. However, the simplicity and practicability of soil and foliar application make them widely accepted among these methods. Several studies confirmed the positive role of soil Se fertilization in various crops/plants such as rice [24, 25], maize [26], wild barley [27], and soybean [28]. The foliar Se application has been reported to significantly promote growth in vegetables such as onion bulbs and leaves [29], carrot roots and leaves 
[30], radish flowers and leaves [31], garlic bulbs [32], and cereals like wheat [33].

The uptake and accumulation of Se within a narrow range are beneficial for plants [34] and are determined by the plants ability to absorb and metabolize Se. It is well documented that increase in acidity, iron oxides/hydroxides, and organic matter and high clay content of soil decrease the bioavailability of Se to plants $[35,36]$. The soil moisture also affects the availability of Se to plants as it is more available under low precipitation conditions [6]. Moreover, actively growing tissues usually contain large amounts of Se [37] and accumulation is higher in shoot and leaf than in root tissues [38]. Therefore, Se fertigation and foliar spray are much more viable and effective approaches than soil application to increase Se translocation within plants. This study was conducted with the hypothesis that Se supply mitigates adverse effects of water stress in wheat seedlings.

\section{Materials and Methods}

2.1. Seed Material and Experimental Design. Two pot experiments were conducted in wire/green house to determine appropriate rates of Se application as fertigation and foliar spray, effective in improving the drought tolerance and biomass in wheat plants subjected to water stress at seedling stage. The seeds of two recommended spring wheat genotypes, that is, Kohistan-97 and Pasban-90, categorized as drought tolerant and sensitive, respectively, in our earlier reports [39], were used for the study. The seeds were obtained from Ayyub Agricultural Research Institute (AARI), Faisalabad (Pakistan). The experiments were laid out in the completely randomized design (CRD) with three repeats. Each repeat consisted of a 10 -seedling pot in each experiment. Twenty randomly selected seeds of each genotype were sterilized with 5\% sodium hypochlorite solution for five minutes and later air-dried to their original moisture level before conducting experiments.

2.2. Drought Stress Treatments. In each experiment, ten seeds of each genotype were sown at $100 \%$ field capacity $(100 \%$ FC) in plastic pots ( 8 dia $\times 12$ length $\mathrm{cm}$ ) containing $430 \mathrm{~g}$ of sterilized, washed, fine river sand. One set of pots (control) was watered regularly while water stress was imposed in the other set of pots by stopping water application after seedling emergence. Amount of water evaporated was calculated daily and control plants were rewatered accordingly. The pots were placed under controlled temperature at $25^{\circ} \mathrm{C}, 16 \mathrm{~h}$ day length, $200 \mu \mathrm{mol} \mathrm{m}^{-2} \mathrm{~s}^{-1}$ photosynthetic active radiation (PAR), and $75-80 \%$ relative humidity for four weeks in growth chamber (Sanyo-Gallenkamp, UK). After four weeks, five plants were harvested randomly from each pot for the calculation of physiological indices. The seedlings were placed in an oven at $65^{\circ} \mathrm{C}$ for 72 hours to record seedling dry weight. Both experiments were repeated thrice and the data presented is the mean of values obtained in three experiments.

2.3. Selenium ( $\mathrm{Se}$ ) Treatments. The Se fertigation doses of $3.68\left(0.25 \mathrm{mg} \mathrm{L}^{-1}\right), 7.35\left(0.50 \mathrm{mg} \mathrm{L}^{-1}\right), 11.03\left(0.75 \mathrm{mg} \mathrm{L}^{-1}\right)$, and $14.70 \mu \mathrm{M}\left(1.00 \mathrm{mg} \mathrm{L}^{-1}\right)$ and Se foliar treatments of 1.76 $\left(0.12 \mathrm{mg} \mathrm{L}^{-1}\right), 3.53\left(0.24 \mathrm{mg} \mathrm{L}^{-1}\right), 5.29\left(0.36 \mathrm{mg} \mathrm{L}^{-1}\right)$, and $7.06 \mu \mathrm{M}\left(0.48 \mathrm{mg} \mathrm{L}^{-1}\right)$ were developed by dissolving $\mathrm{Na}_{2} \mathrm{SeO}_{4}$ (Sigma-Aldrich, USA) in distilled water. The seedlings were fertigated and foliarly sprayed with Se after three days of exposure to stress.

The following formulae as described by [40] were used for the calculation of plant height stress tolerance index (PHSI), root length stress tolerance index (RLSI), and fresh and dry matter stress tolerance indices (FMSI, DMSI).

PHSI $(\%)=$ [plant height of stressed plant $/$ plant height of control plant] $\times 100$;

DMSI $(\%)=[$ dry matter of stressed plant/dry matter of control plant] $\times 100$;

RLSI $(\%)=[$ root length of stressed plant/root length of control plant] $\times 100$;

SFSI $(\%)=[$ shoot fresh weights of stressed plants/shoot fresh weights of control plants] $\times$ 100 ;

RFSI (\%) $=[$ root fresh weights of stressed plants/root fresh weights of control plants] $\times 100$.

2.4. Statistical Analysis. All the recoded data in different experiments during this study were analyzed statistically using analysis of variance technique and STATISTICA Computer Program was used for this purpose. Tukey test at 5\% probability level was used to compare means.

\section{Results}

The highly significant effect $(P<0.01)$ of Se fertigation and foliar spray was recorded on physiological indices of both wheat genotypes (Kohistan-97 and Pasban-90). The maximum PHSI value (86\%) was noted in seedlings fertigated with $7.35 \mu \mathrm{M}$ Se, whereas low PHSI values were recorded at high $(11.03 \mu \mathrm{M}$ and $14.70 \mu \mathrm{M})$ or low levels $(3.68 \mu \mathrm{M})$ of Se fertigation (Figure 1). A gradual increase in PHSI was observed by increasing Se foliar spray levels. The application of Se at $7.06 \mu \mathrm{M}$ gave the maximum value (88\%) for this index, while the minimum value $(63 \%)$ was recorded in seedlings sprayed with water which was statistically at par with the value (64\%) obtained for the lowest Se treatment of $1.76 \mu \mathrm{M}$ (Figure 1). Nonsignificant differences were recorded between genotypes in both Se supply methods (Se fertigation and Se foliar spray) for PHSI (Figure 1).

The highest value for RLSI (159\%) was recorded in plants supplied with $7.35 \mu \mathrm{M}$ Se. A nonsignificant difference $(P>$ 0.05 ) was observed between high Se treatments, that is, $11.03 \mu \mathrm{M}$ and $14.70 \mu \mathrm{M}$, which had RLSI values of $150 \%$ and $152 \%$, respectively, whereas the lowest value for RLSI (141\%) was recorded in seedlings fertigated with $3.68 \mu \mathrm{M}$ Se (Figure 2). The plants foliarly sprayed with $7.06 \mu \mathrm{M}$ Se maintained maximum value (121\%) for RLSI, which was $15 \%$ higher as compared to water sprayed seedlings (103\%). The foliar application of Se at $3.53 \mu \mathrm{M}$ and $5.29 \mu \mathrm{M}$ increased RLSI by $8 \%$ and $12 \%$, respectively, as compared to water sprayed 

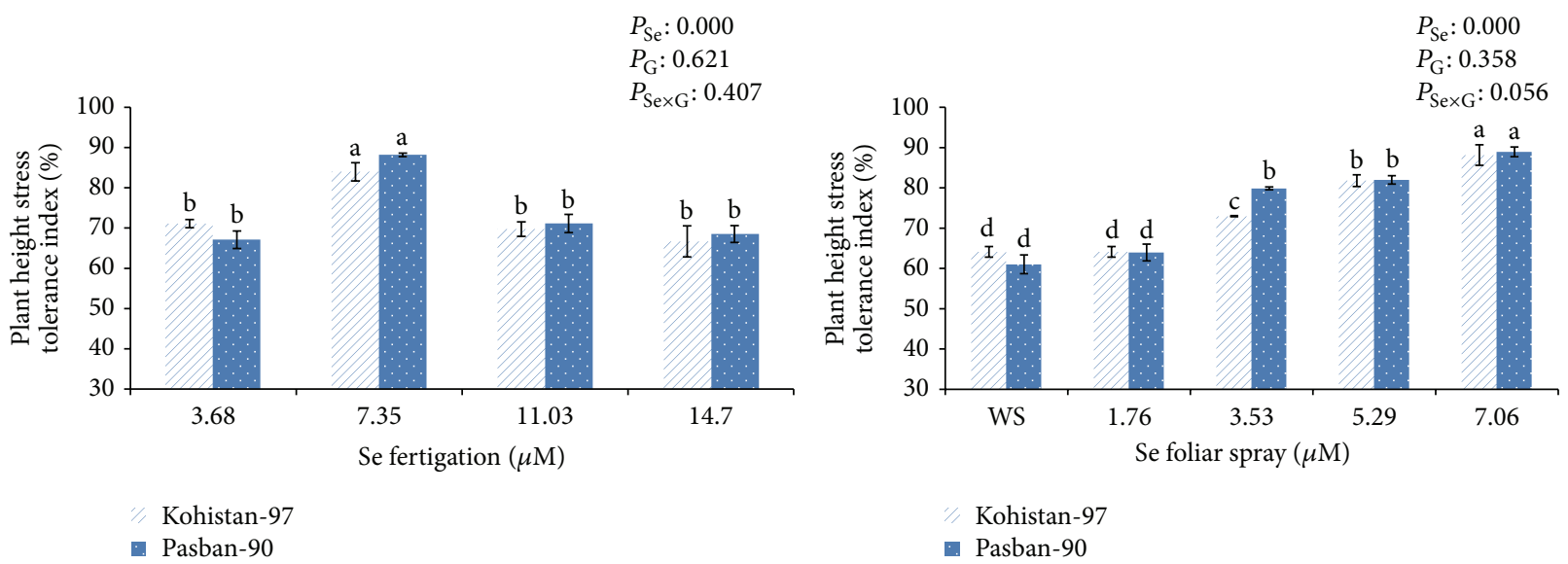

FIGURE 1: Effect of Se fertigation and Se foliar spray on plant height stress tolerance index (PHSI) of wheat seedlings. Fertigation treatments include fertigation with $3.68\left(0.25 \mathrm{mg} \mathrm{L}^{-1}\right)$, $7.35\left(0.50 \mathrm{mg} \mathrm{L}^{-1}\right)$, $11.03\left(0.75 \mathrm{mg} \mathrm{L}^{-1}\right)$, and $14.70 \mu \mathrm{M}\left(1.00 \mathrm{mg} \mathrm{L}^{-1}\right)$, whereas foliar treatments include foliar spray with water (WS) and Se foliar spray with $1.76\left(0.12 \mathrm{mg} \mathrm{L}^{-1}\right), 3.53\left(0.24 \mathrm{mg} \mathrm{L}^{-1}\right), 5.29\left(0.36 \mathrm{mg} \mathrm{L}^{-1}\right)$, and $7.06 \mu \mathrm{M}$ $\left(0.48 \mathrm{mg} \mathrm{L}^{-1}\right)$. Values are mean \pm standard error. $P_{\mathrm{Se}}$ : Se effects; $P_{\mathrm{G}}$ : genotype effects; $P_{\mathrm{SexG}}$ : interaction effects of Se and genotypes.

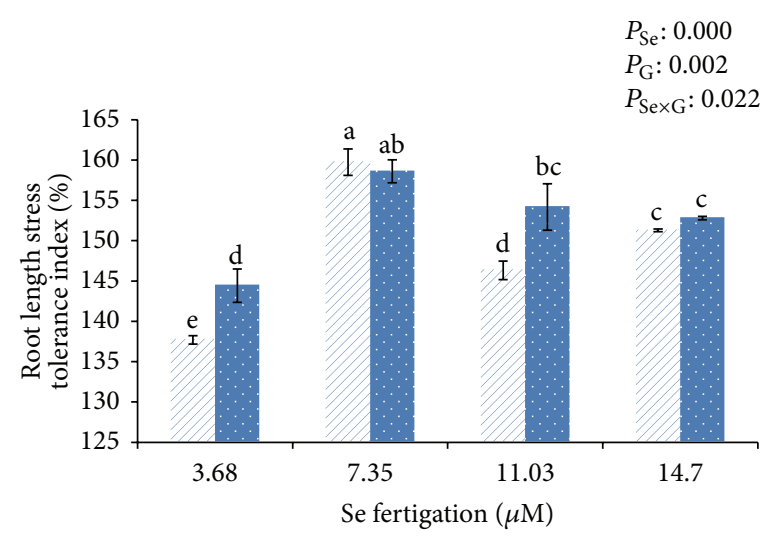

Kohistan-97

- Pasban-90

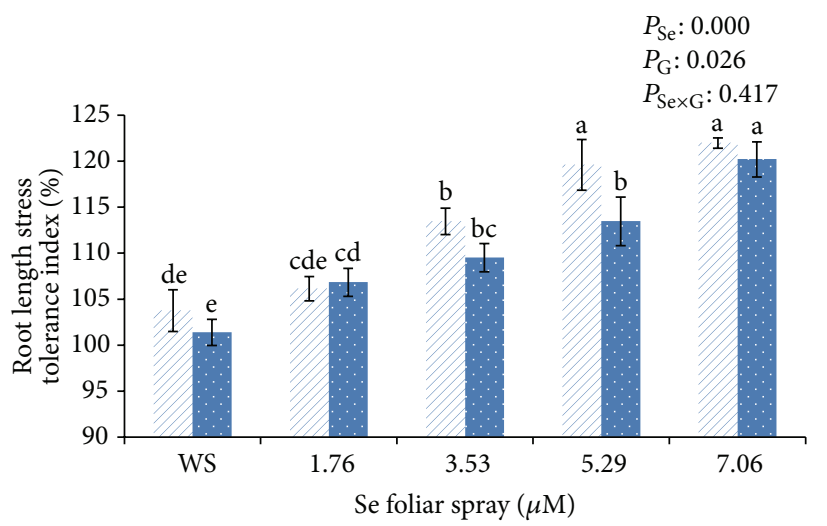

Kohistan-97

. Pasban-90

FIGURE 2: Effect of Se fertigation and Se foliar spray on root length stress tolerance index (RLSI) of wheat seedlings. Fertigation treatments include fertigation with $3.68\left(0.25 \mathrm{mg} \mathrm{L}^{-1}\right), 7.35\left(0.50 \mathrm{mg} \mathrm{L}^{-1}\right), 11.03\left(0.75 \mathrm{mg} \mathrm{L}^{-1}\right)$, and $14.70 \mu \mathrm{M}\left(1.00 \mathrm{mg} \mathrm{L}^{-1}\right)$, whereas foliar treatments include foliar spray with water (WS) and Se foliar spray with $1.76\left(0.12 \mathrm{mg} \mathrm{L}^{-1}\right), 3.53\left(0.24 \mathrm{mg} \mathrm{L}^{-1}\right), 5.29\left(0.36 \mathrm{mg} \mathrm{L}^{-1}\right)$, and $7.06 \mu \mathrm{M}$ $\left(0.48 \mathrm{mg} \mathrm{L}^{-1}\right)$. Values are mean \pm standard error. $P_{\mathrm{Se}}$ : Se effects; $P_{\mathrm{G}}$ : genotype effects; $P_{\mathrm{SexG}}$ : interaction effects of Se and genotypes.

seedlings (Figure 2). The results showed that Se fertigated plants maintained $31 \%$ higher RLSI than those foliarly applied with Se.

The fertigation of seedlings with $7.35 \mu \mathrm{M}$ and $11.03 \mu \mathrm{M}$ Se gave the maximum value (72\%) for DMSI, whereas at Se fertigation level of $3.68 \mu \mathrm{M}$ the minimum value (67\%) was recorded (Figure 3). The seedlings applied with foliar Se treatment of $7.06 \mu \mathrm{M}$ showed an increase of $85 \%$ and had maximum value $(89 \%)$ as compared to plants sprayed with water exhibiting minimum value (48\%) for DMSI. The foliar spray of plants with Se resulted in 33\% higher DMSI than Se fertigation (Figure 3). Wheat genotype Kohistan-97 showed significantly higher RLSI and DMSI than Pasban-90 in both Se supply methods, that is, Se fertigation and foliar spray (Figures 2 and 3).

The plants fertigated with $7.35 \mu \mathrm{M}$ Se exhibited the highest values for SFSI (53\%) and RFSI (80\%). The higher Se fertigation levels of $11.03 \mu \mathrm{M}$ and $14.70 \mu \mathrm{M}$ also increased SFSI and RFSI and were statistically related to each other for these indices (Figures 4 and 5). The lowest dose of Se fertigation $(3.68 \mu \mathrm{M})$ resulted in minimum SFSI and RFSI, that is, $44 \%$ and $63 \%$, respectively. In seedlings foliarly applied with Se, the foliar Se treatment of $7.06 \mu \mathrm{M}$ gave the maximum values for SFSI (85\%) and RFSI (80\%) (Figure 4). It was observed that Se foliar spray was more effective $(60 \%)$ than Se fertigation in enhancing SFSI of the seedlings (Figure 4), whereas a nonsignificant difference was observed between $\mathrm{Se}$ supply methods for RFSI (Figure 5).

\section{Discussion}

The results indicate that water stress adversely influences wheat growth due to poor germination and seedling establishment. It was observed that fertigation and foliar spray are 


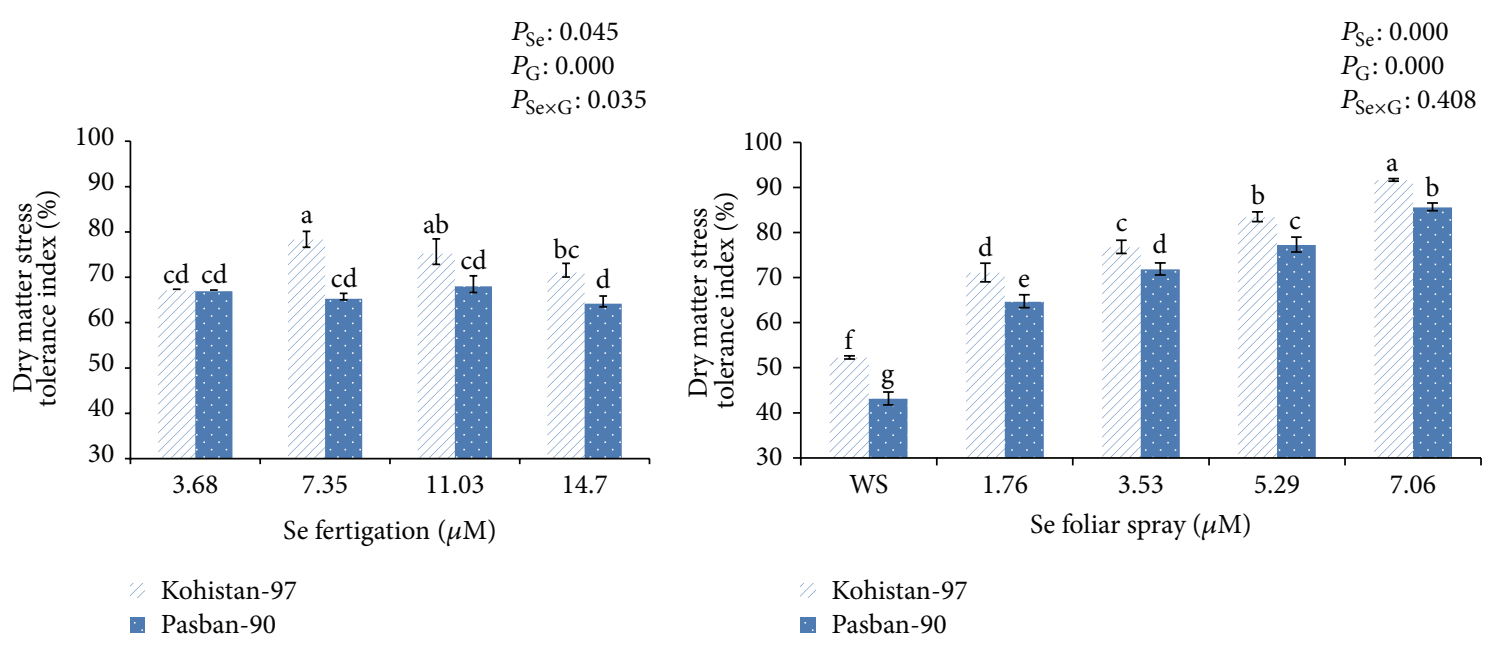

FIGURE 3: Effect of Se fertigation and Se foliar spray on dry matter stress tolerance index (DMSI) of wheat seedlings. Fertigation treatments include fertigation with $3.68\left(0.25 \mathrm{mg} \mathrm{L}^{-1}\right), 7.35\left(0.50 \mathrm{mg} \mathrm{L}^{-1}\right), 11.03\left(0.75 \mathrm{mg} \mathrm{L}^{-1}\right)$, and $14.70 \mu \mathrm{M}\left(1.00 \mathrm{mg} \mathrm{L}^{-1}\right)$, whereas foliar treatments include foliar spray with water (WS) and Se foliar spray with $1.76\left(0.12 \mathrm{mg} \mathrm{L}^{-1}\right), 3.53\left(0.24 \mathrm{mg} \mathrm{L}^{-1}\right), 5.29\left(0.36 \mathrm{mg} \mathrm{L}^{-1}\right)$, and $7.06 \mu \mathrm{M}$ $\left(0.48 \mathrm{mg} \mathrm{L}^{-1}\right)$. Values are mean \pm standard error. $P_{\mathrm{Se}}$ : Se effects; $P_{\mathrm{G}}$ : genotype effects; $P_{\mathrm{SexG}}$ : interaction effects of Se and genotypes.

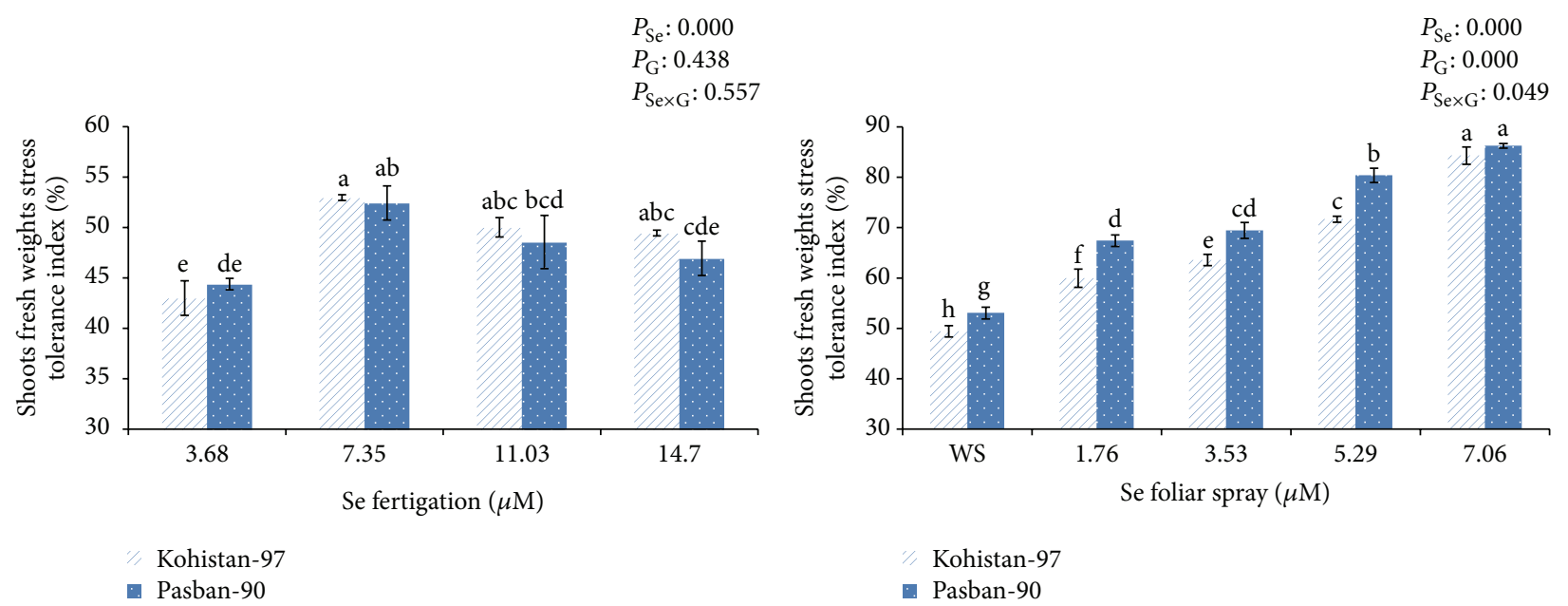

Figure 4: Effect of Se fertigation and Se foliar spray on shoots fresh weights stress tolerance index (SFSI) of wheat seedlings. Fertigation treatments include fertigation with $3.68\left(0.25 \mathrm{mg} \mathrm{L}^{-1}\right), 7.35\left(0.50 \mathrm{mg} \mathrm{L}^{-1}\right), 11.03\left(0.75 \mathrm{mg} \mathrm{L}^{-1}\right)$, and $14.70 \mu \mathrm{M}\left(1.00 \mathrm{mg} \mathrm{L}^{-1}\right)$, whereas foliar treatments include foliar spray with water (WS) and Se foliar spray with $1.76\left(0.12 \mathrm{mg} \mathrm{L}^{-1}\right), 3.53\left(0.24 \mathrm{mg} \mathrm{L}^{-1}\right), 5.29\left(0.36 \mathrm{mg} \mathrm{L}^{-1}\right)$, and $7.06 \mu \mathrm{M}$ $\left(0.48 \mathrm{mg} \mathrm{L}^{-1}\right)$. Values are mean \pm standard error. $P_{\mathrm{Se}}$ : Se effects; $P_{\mathrm{G}}$ : genotype effects; $P_{\mathrm{SexG}}$ : interaction effects of Se and genotypes.

efficient, viable, and effective approaches for the application of fertilizers and improving fertilizer use efficiency [41]. An increase in physiological indices with Se supply confirmed the hypothesis that Se plays a positive role in improving drought tolerance of wheat seedlings.

The increase in PHSI specifies Se role in regulation of water status of moisture stressed seedlings [42] and activation of plant hormones responsible for cell expansion and enlargement [43]. The maximum PHSI observed by Se fertigation treatment of $7.35 \mu \mathrm{M}$ (Figure 1) and Se foliar application at $7.06 \mu \mathrm{M}$ (Figure 1) might be attributed to the Se-regulated decrease in osmotic potential that increases the water relations of water stressed seedlings [44]. The actively growing plant parts such as young leaves and seeds accumulate large amounts of Se which affects osmoregulation in plants $[37,45]$.

The growth and development of plants is directly influenced by root activity [46] so it can serve as an important index of plant resistance [20]. The increase in root length is an adaptive response of wheat plants exposed to drought stress. The highest RLSI recorded in plants fertigated (Figure 2) and foliarly sprayed (Figure 2) with Se treatments of $7.35 \mu \mathrm{M}$ and $7.06 \mu \mathrm{M}$, respectively, indicates the effectiveness of Se in improving plant resistance against drought stress. The radicles treated with Se are healthier and vigorous with extensive root hairs [47]. Yao et al. [20] reported an increase in root activity (growth and uptake) of water stressed seedlings by extra Se supply resulting in an increase in dry matter which 


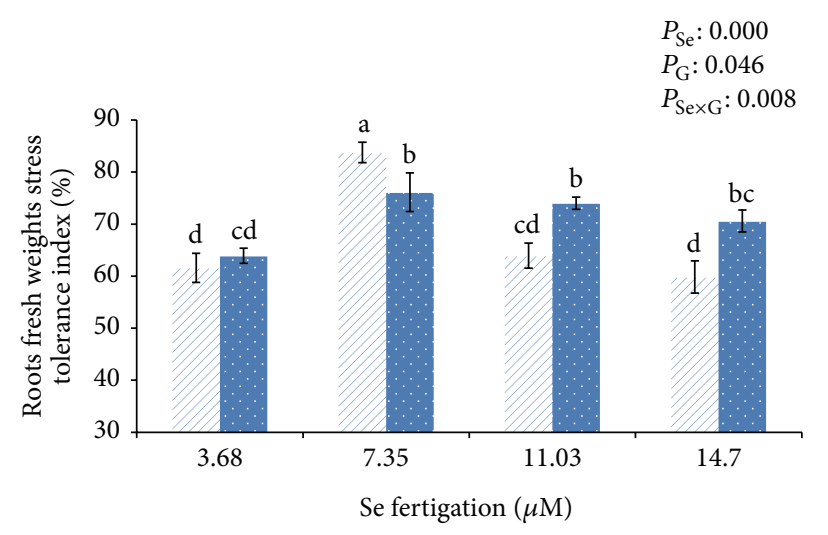

Kohistan-97

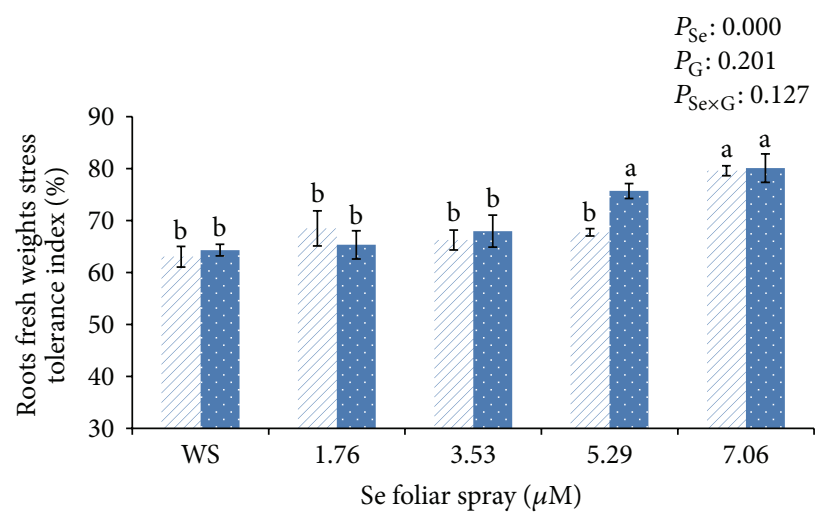

Kohistan-97

. Pasban-90

FIgURE 5: Effect of Se fertigation and Se foliar spray on roots fresh weights stress tolerance index (RFSI) of wheat seedlings. Fertigation treatments include fertigation with $3.68\left(0.25 \mathrm{mg} \mathrm{L}^{-1}\right), 7.35\left(0.50 \mathrm{mg} \mathrm{L}^{-1}\right), 11.03\left(0.75 \mathrm{mg} \mathrm{L}^{-1}\right)$, and $14.70 \mu \mathrm{M}\left(1.00 \mathrm{mg} \mathrm{L}^{-1}\right)$, whereas foliar treatments include foliar spray with water (WS) and Se foliar spray with $1.76\left(0.12 \mathrm{mg} \mathrm{L}^{-1}\right), 3.53\left(0.24 \mathrm{mg} \mathrm{L}^{-1}\right), 5.29\left(0.36 \mathrm{mg} \mathrm{L}^{-1}\right)$, and $7.06 \mu \mathrm{M}$ $\left(0.48 \mathrm{mg} \mathrm{L}^{-1}\right)$. Values are mean \pm standard error. $P_{\mathrm{Se}}$ : Se effects; $P_{\mathrm{G}}$ : genotype effects; $P_{\mathrm{SexG}}$ : interaction effects of Se and genotypes.

improved DMSI of seedlings (Figure 3). Similarly, Valadabadi et al. [48] noted a significant increase in total dry weight of rapeseed cultivars foliarly sprayed with Se under water stress conditions. The increase in root length and dry weight by Se application supports the fact that a significant relation exists between root and seedling dry weight of water stressed seedlings $[49,50]$.

The fertigation of seedlings by Se treatment of $7.35 \mu \mathrm{M}$ resulted in the highest biomass accumulation (Figures 4 and 5). However, low Se fertigation doses did not significantly improve the biomass (SFSI and RFSI). These results are in line with the findings of Nawaz et al. [19] who observed that Se significantly increased growth of water stressed wheat seedlings and were of the view that Se regulates water status under drought stress. Nonsignificant effect of lower Se doses on biomass has been reported in wheat [20], perennial ryegrass, and strawberry clover [51]. The high Se fertigation dose $(14.70 \mu \mathrm{M})$ caused a significant reduction in biomass (Figures 4 and 5). Similar results were reported by XiménezEmbún et al. [52] in white lupine (20\%) and sunflower (40\%) at high Se fertilization doses. High levels of Se inhibit photosynthesis by decreasing the light energy absorbed by the antenna system and impair photosynthetic machinery of wheat [53] which results in the lower production of starch $[54,55]$ that may lead to a decrease in the biomass production.

The highest biomass accumulation (SFSI and RFSI) with Se foliar spray (Figures 4 and 5) may be due to the diffusion of Se ions that takes place from the surface of leaves to epidermal cells. The foliar application of Se has been reported to stimulate growth in lettuce [56], green tea [57], and potato [58]. Germ [59] observed significant increase in mass of only water stressed potato tubers supplemented with Se, whereas the mass of tubers was reduced by Se application in wellwatered plants. Similar results were reported by Habibi [60] in barley. The increased Se efficiency by foliar application may be due to its direct absorption and accumulation in the plants by diffusion from the surface of leaves to epidermal cells [61] but its high concentration can cause damage to leaf surface [62]. Therefore, concentration of solution at fertigation and foliar application of Se should be chosen with care, based on recommendations.

\section{Conclusion}

The identification of effective Se dose and method is crucial for better understanding of Se uptake and accumulation in water stressed crop plants. From the results of experiments, it was concluded that Se fertigation at $7.35 \mu \mathrm{M}$ and Se foliar treatment of $7.06 \mu \mathrm{M}$ significantly mitigated the adverse effects of drought stress in wheat seedlings. The difference among Se supply methods (Se fertigation and Se foliar spray) suggests differences in their efficiency for Se uptake in plants. It was observed that Se foliar spray was more effective than Se fertigation in increasing DMSI and biomass (SFSI and RFSI) of seedlings. However, the plants exhibited maximum RLSI by Se fertigation, whereas a nonsignificant difference was recorded between Se application methods for PHSI.

\section{Conflict of Interests}

The authors declare that there is no conflict of interests regarding the publication of this paper.

\section{Acknowledgment}

The authors are grateful to the Higher Education Commission (HEC) of Pakistan for the financial support.

\section{References}

[1] M. M. Chaves and M. M. Oliveira, "Mechanisms underlying plant resilience to water deficits: prospects for water-saving 
agriculture," Journal of Experimental Botany, vol. 55, no. 407, pp. 2365-2384, 2004.

[2] J. J. Zhang, G. P. Hao, Z. Y. Wu et al., "Nucleotide variation in ATHK1 region of Arabidopsis thaliana and its association study with drought tolerance," African Journal of Biotechnology, vol. 7, no. 3, pp. 224-233, 2008.

[3] F. Nawaz, R. Ahmad, E. A. Waraich, M. S. Naeem, and R. N. Shabbir, "Nutrient uptake, physiological responses, and yield attributes of wheat (Triticum aestivum 1.) exposed to early and late drought stress," Journal of Plant Nutrition, vol. 35, no. 6, pp. 961-974, 2012.

[4] C. M. Ashraf and S. Abu-Shakra, "Wheat seed germination under low temperature and moisture stress," Agron Journal, vol. 70, pp. 135-139, 1978.

[5] X. Tian and Y. Lei, "Nitric oxide treatment alleviates drought stress in wheat seedlings," Biologia Plantarum, vol. 50, no. 4, pp. 775-778, 2006.

[6] F. Zhao, F. J. Lopez-Bellido, C. W. Gray, W. R. Whalley, L. J. Clark, and S. P. McGrath, "Effects of soil compaction and irrigation on the concentrations of selenium and arsenic in wheat grains," Science of the Total Environment, vol. 372, no. 2-3, pp. 433-439, 2007.

[7] B. Hanson, G. F. Garifullina, S. D. Lindblom et al., "Selenium accumulation protects Brassica juncea from invertebrate herbivory and fungal infection," New Phytologist, vol. 159, no. 2, pp. 461-469, 2003.

[8] M. Seppänen, M. Turakainen, and H. Hartikainen, "Selenium effects on oxidative stress in potato," Plant Science, vol. 165, no. 2, pp. 311-319, 2003.

[9] M. Kumar, A. J. Bijo, R. S. Baghel, C. R. K. Reddy, and B. Jha, "Selenium and spermine alleviate cadmium induced toxicity in the red seaweed Gracilaria dura by regulating antioxidants and DNA methylation," Plant Physiology and Biochemistry, vol. 51, pp. 129-138, 2012.

[10] X. Yao, J. Chu, and C. Ba, "Antioxidant responses of wheat seedlings to exogenous selenium supply under enhanced ultravioletB," Biological Trace Element Research, vol. 136, no. 1, pp. 96-105, 2010.

[11] X. Q. Yao, J. Z. Chu, and C. J. Ba, "Responses of wheat roots to exogenous selenium supply under enhanced ultraviolet-B," Biological Trace Element Research, vol. 137, no. 2, pp. 244-252, 2010.

[12] C. Wang, "Water-stress mitigation by selenium in Trifolium repens L.," Journal of Plant Nutrition and Soil Science, vol. 174, no. 2, pp. 276-282, 2011.

[13] M. Hasanuzzaman, M. A. Hossain, and M. Fujita, "Seleniuminduced up-regulation of the antioxidant defense and methylglyoxal detoxification system reduces salinity-induced damage in rapeseed seedlings," Biological Trace Element Research, vol. 143, no. 3, pp. 1704-1721, 2011.

[14] J. Chu, X. Yao, and Z. Zhang, "Responses of wheat seedlings to exogenous selenium supply under cold stress," Biological Trace Element Research, vol. 136, no. 3, pp. 355-363, 2010.

[15] M. Djanaguiraman, P. V. V. Prasad, and M. Seppanen, "Selenium protects sorghum leaves from oxidative damage under high temperature stress by enhancing antioxidant defense system," Plant Physiology and Biochemistry, vol. 48, no. 12, pp. 999-1007, 2010.

[16] H. Hartikainen, T. Xue, and V. Piironen, "Selenium as an antioxidant and pro-oxidant in ryegrass," Plant and Soil, vol. 225, no. 1-2, pp. 193-200, 2000.
[17] S. Pukacka, E. Ratajczak, and E. Kalemba, “The protective role of selenium in recalcitrant Acer saccharium L. seeds subjected to desiccation," Journal of Plant Physiology, vol. 168, no. 3, pp. 220-225, 2011.

[18] V. V. Kuznetsov, V. P. Kholodova, V. I. V. Kuznetsov, and B. A. Yagodin, "Selenium regulates the water status of plants exposed to drought," Doklady Biological Sciences, vol. 390, pp. 266-268, 2003.

[19] F. Nawaz, M. Y. Ashraf, R. Ahmad, and E. A. Waraich, "Selenium (Se) seed priming induced growth and biochemical changes in wheat under water deficit conditions," Biological Trace Element Research, vol. 151, no. 2, pp. 284-293, 2013.

[20] X. Yao, J. Chu, and G. Wang, "Effects of selenium on wheat seedlings under drought stress," Biological Trace Element Research, vol. 130, no. 3, pp. 283-290, 2009.

[21] M. Hasanuzzaman and M. Fujita, "Selenium pretreatment upregulates the antioxidant defense and methylglyoxal detoxification system and confers enhanced tolerance to drought stress in rapeseed seedlings," Biological Trace Element Research, vol. 143, no. 3, pp. 1758-1776, 2011.

[22] S. Bittman, W. T. Buckley, K. Zaychuk, and E. A. P. Brown, "Seed coating for enhancing the level of selenium in crops," USA Patent No. 6,058, 649, 2000.

[23] L. D. Temmerman, N. Waegeneers, C. Thiry, G. D. Laing, F. Tack, and A. Ruttens, "Selenium content of Belgian cultivated soils and its uptake by field crops and vegetables," Science of the Total Environment, vol. 468-469, pp. 77-82, 2013.

[24] P. F. Boldrin, V. Faquin, S. J. Ramos, K. V. F. Boldrin, F. W. Ávila, and L. R. G. Guilherme, "Soil and foliar application of selenium in rice biofortification," Journal of Food Composition and Analysis, vol. 31, pp. 238-244, 2013.

[25] Y. Wang, X. Wang, and Y. Wong, "Generation of seleniumenriched rice with enhanced grain yield, selenium content and bioavailability through fertilisation with selenite," Food Chemistry, vol. 141, no. 3, pp. 2385-2393, 2013.

[26] A. D. C. Chilimba, S. D. Young, C. R. Black, M. C. Meacham, J. Lammel, and M. R. Broadley, "Agronomic biofortification of maize with selenium (Se) in Malawi," Field Crops Research, vol. 125, pp. 118-128, 2012.

[27] J. Yan, F. Wang, H. Qin et al., "Natural Variation in Grain Selenium Concentration of Wild Barley, Hordeum spontaneum, Populations from Israel," Biological Trace Element Research, vol. 142, no. 3, pp. 773-786, 2011.

[28] F. Yang, L. Chen, Q. Hu, and G. Pan, "Effect of the application of selenium on selenium content of soybean and its products," Biological Trace Element Research, vol. 93, no. 1-3, pp. 249-256, 2003.

[29] E. Kápolna, K. H. Laursen, S. Husted, and E. H. Larsen, "Biofortification and isotopic labelling of Se metabolites in onions and carrots following foliar application of Se and ${ }^{77} \mathrm{Se}$," Food Chemistry, vol. 133, no. 3, pp. 650-657, 2012.

[30] E. Kápolna, P. R. Hillestrøm, K. H. Laursen, S. Husted, and E. H. Larsen, "Effect of foliar application of selenium on its uptake and speciation in carrot," Food Chemistry, vol. 115, no. 4, pp. 1357-1363, 2009.

[31] K. R. Hladun, D. R. Parker, K. D. Tran, and J. T. Trumble, "Effects of selenium accumulation on phytotoxicity, herbivory, and pollination ecology in radish (Raphanus sativus L.)," Environmental Pollution, vol. 172, pp. 70-75, 2013.

[32] P. Põldma, T. Tõnutare, A. Viitak, A. Luik, and U. Moor, "Effect of selenium treatment on mineral nutrition, bulb size, and 
antioxidant properties of garlic (Allium sativum L.)," Journal of Agricultural and Food Chemistry, vol. 59, no. 10, pp. 5498-5503, 2011.

[33] D. Curtin, R. Hanson, T. N. Lindley, and R. C. Butler, "Selenium concentration in wheat (Triticum aestivum) grain as influenced by method, rate, and timing of sodium selenate application," New Zealand Journal of Crop and Horticultural Science, vol. 34, no. 4, pp. 329-339, 2006.

[34] N. Terry, A. M. Zayed, M. P. de Souza, and A. S. Tarun, "Selenium in higher plants," Annual Review of Plant Physiology and Plant Molecular Biology, vol. 51, pp. 401-432, 2000.

[35] R. L. Mikkelsen, A. L. Page, and F.T. Bingham, "Factors affecting selenium accumulation by agricultural crops," in Selenium in Agriculture and the Environment, L. W. Jacobs, Ed., SSSA Special Publication Number 23, pp. 65-94, Soil Science Society of America, Madison, Wis, USA, 1989.

[36] A. Kabata-Pendias and H. Pendias, Trace Elements in Soils and Plants, CRC Press, Boca Raton, Fla, USA, 2nd edition, 1992.

[37] C. Kahakachchi, H. T. Boakye, P. C. Uden, and J. F. Tyson, "Chromatographic speciation of anionic and neutral selenium compounds in Se-accumulating Brassica juncea (Indian mustard) and in selenized yeast," Journal of Chromatography A, vol. 1054, no. 1-2, pp. 303-312, 2004.

[38] A. Zayed, C. M. Lytle, and N. Terry, "Accumulation and volatilization of different chemical species of selenium by plants," Planta, vol. 206, no. 2, pp. 284-292, 1998.

[39] M. Y. Ashraf, F. Hussain, J. Akhter, A. Gul, M. Ross, and G. Ebert, "Effect of different sources and rates of nitrogen and supra optimal level of potassium fertilization on growth, yield and nutrient uptake by sugarcane grown under saline conditions," Pakistan Journal of Botany, vol. 40, no. 4, pp. 15211531, 2008.

[40] F. Nawaz, Wheat response to exogenous selenium supply under drought stress [Ph.D. dissertation], University of Agriculture, Faisalabad, Pakistan, 2014.

[41] A. Latif and M. M. Iqbal, "Fertigation techniques," in Proceedings of the Workshop on Technologies for Sustainable Agriculture (NIAB '01), pp. 155-159, Faisalabad, Pakistan, 2001.

[42] M. Djanaguiraman, D. D. Devi, A. K. Shanker, J. A. Sheeba, and U. Bangarusamy, "Selenium-an antioxidative protectant in soybean during senescence," Plant and Soil, vol. 272, no. 1-2, pp. 77-86, 2005.

[43] K. L. Larson, "Drought injury and resistance of crop plants," in Physiological Aspects of Dry Land Farming, S. U. Gupta, Ed., pp. 147-162, Oxford \& IBH Publishing, New Delhi, India, 1992.

[44] H. Hartikainen, "Biogeochemistry of selenium and its impact on food chain quality and human health," Journal of Trace Elements in Medicine and Biology, vol. 18, no. 4, pp. 309-318, 2005.

[45] P. Smrkolj, M. Osvald, J. Osvald, and V. Stibilj, "Selenium uptake and species distribution in selenium-enriched bean (Phaseolus vulgaris L.) seeds obtained by two different cultivations," European Food Research and Technology, vol. 225, no. 2, pp. 233-237, 2007.

[46] B. Z. Bai, J. Z. Jin, S. Bai, and L. P. Huang, "Improvement of TTC method determining root activity in corn," Maize Science, vol. 2, pp. 44-47, 1994 (Chinese).

[47] C. L. Carlson, D. I. Kaplan, and D. C. Adriano, "Effects of selenium on germination and radicle elongation of selected agronomic species," Environmental and Experimental Botany, vol. 29, no. 4, pp. 493-498, 1989.
[48] S. A. Valadabadi, A. H. Shiranirad, and H. A. Farahani, "Ecophysiological influences of zeolite and selenium on water deficit stress tolerance in different rapeseed cultivars," Journal of Ecology and the Natural Environment, vol. 2, pp. 154-159, 2010.

[49] G. Okçu, M. D. Kaya, and M. Atak, "Effects of salt and drought stresses on germination and seedling growth of pea (Pisum sativum L.)," Turkish Journal of Agriculture and Forestry, vol. 29, no. 4, pp. 237-242, 2005.

[50] M. Yağmur and D. Kaydan, "Alleviation of osmotic stress of water and salt in germination and seedling growth of triticale with seed priming treatments," African Journal of Biotechnology, vol. 7, no. 13, pp. 2156-2162, 2008.

[51] J. L. Hopper and D. R. Parker, "Plant availability of selenite and selenate as influenced by the competing ions phosphate and sulfate," Plant and Soil, vol. 210, no. 2, pp. 199-207, 1999.

[52] P. Ximénez-Embún, I. Alonso, Y. Madrid-Albarran, and C. Camara, "Establishment of selenium uptake and species distribution in lupine, Indian mustard, and sunflower plants," Journal of Agricultural and Food Chemistry, vol. 52, pp. 832-838, 2004.

[53] M. Łabanowska, M. Filek, J. Kościelniak, M. Kurdziel, E. Kuliś, and H. Hartikainen, "The effects of short-term selenium stress on Polish and Finnish wheat seedlings-EPR, enzymatic and fluorescence studies," Journal of Plant Physiology, vol. 169, no. 3, pp. 275-284, 2012.

[54] M. Vítová, K. Bišová, M. Hlavová, V. Zachleder, M. Rucki, and M. Cížková, "Glutathione peroxidase activity in the seleniumtreated alga Scenedesmus quadricauda," Aquatic Toxicology, vol. 102, no. 1-2, pp. 87-94, 2011.

[55] Y. Wang, X. Wang, and Y. Wong, "Proteomics analysis reveals multiple regulatory mechanisms in response to selenium in rice," Journal of Proteomics, vol. 75, no. 6, pp. 1849-1866, 2012.

[56] T. Xue, H. Hartikainen, and V. Piironen, "Antioxidative and growth-promoting effect of selenium on senescing lettuce," Plant and Soil, vol. 237, no. 1, pp. 55-61, 2001.

[57] Q. Hu, G. Pan, and J. Zhu, "Effect of selenium on green tea preservation quality and amino acid composition of tea protein," Journal of Horticultural Science and Biotechnology, vol. 76, no. 3, pp. 344-346, 2001.

[58] M. Turakainen, H. Hartikainen, and M. M. Seppänen, "Effects of selenium treatments on potato (Solanum tuberosum L.) growth and concentrations of soluble sugars and starch," Journal of Agricultural and Food Chemistry, vol. 52, no. 17, pp. 53785382, 2004.

[59] M. Germ, "The response of two potato cultivars on combined effects of selenium and drought," Acta Agriculturae Slovenica, vol. 91, no. 1, pp. 121-137, 2008.

[60] G. Habibi, "Effect of drought stress and selenium spraying on photosynthesis and antioxidant activity of spring barley," Acta Agriculturae Slovenica, vol. 101, no. 1, pp. 31-39, 2013.

[61] P. Wójcik, "Uptake of mineral nutrients from foliar fertilization," Journal of Fruit and Ornamental Plant Research, vol. 12, pp. 201-218, 2004.

[62] H. Marschner, Mineral Nutrition of Higher Plants, Academic Press, London, UK, 1995. 

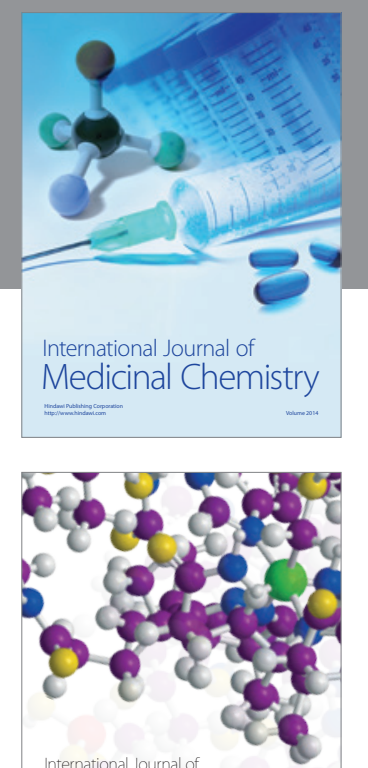

\section{Carbohydrate} Chemistry

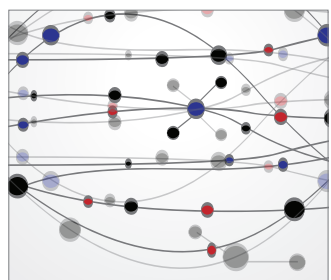

The Scientific World Journal
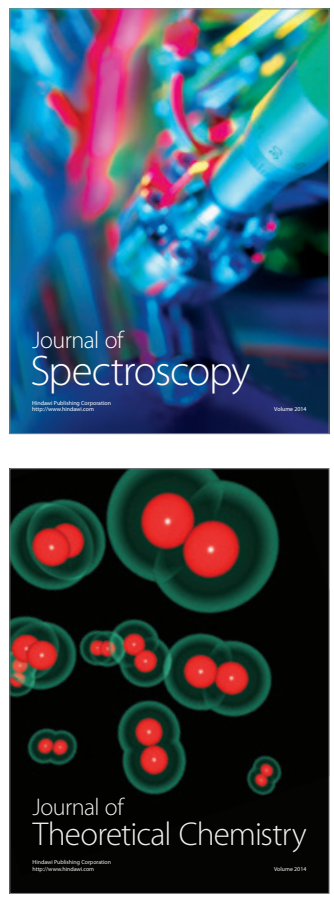
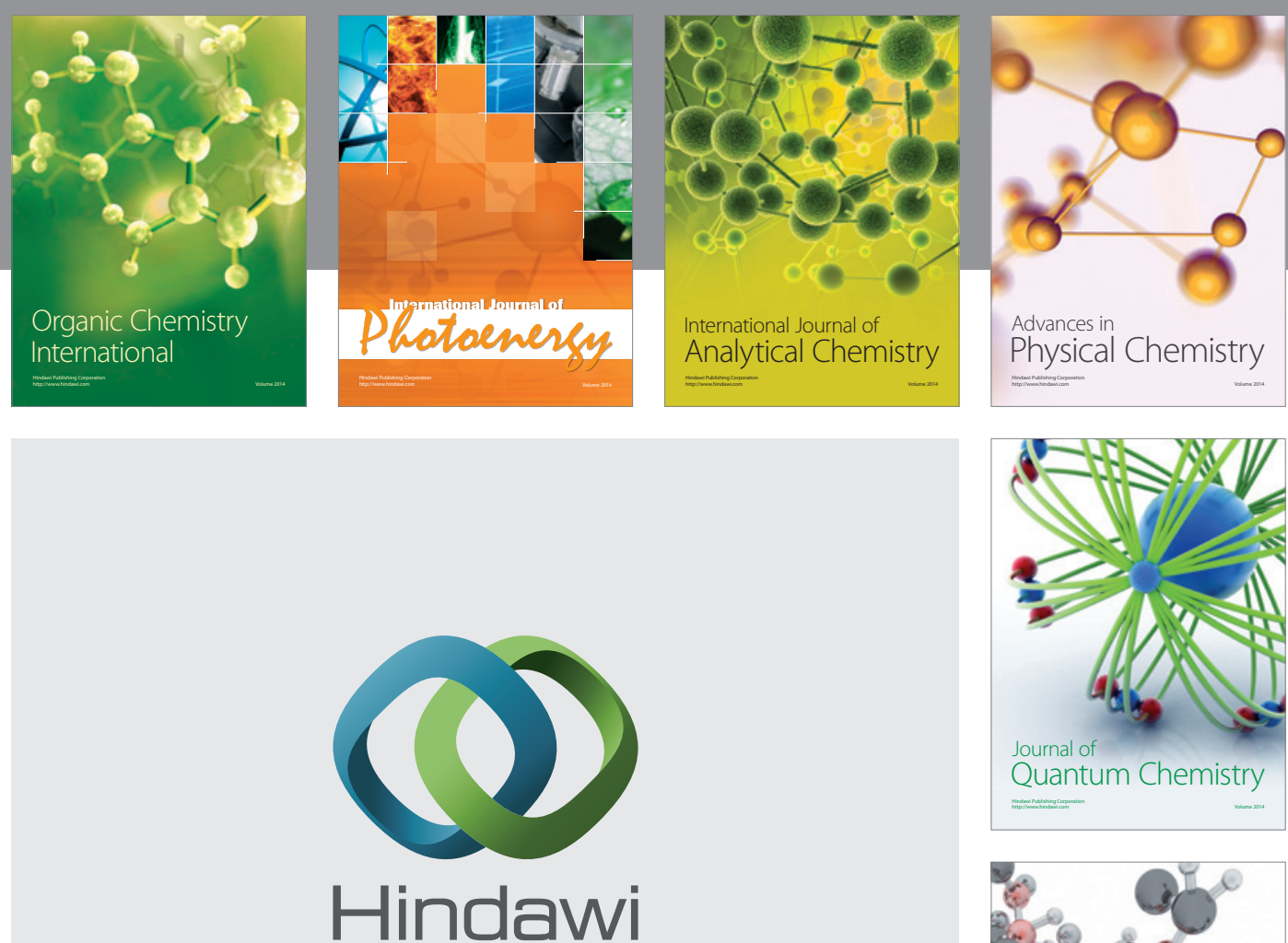

Submit your manuscripts at

http://www.hindawi.com

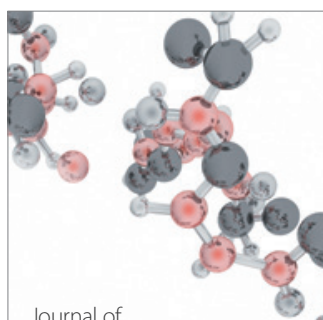

Analytical Methods

in Chemistry

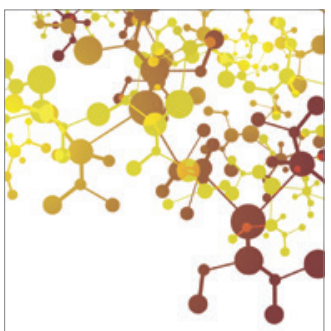

Journal of

Applied Chemistry

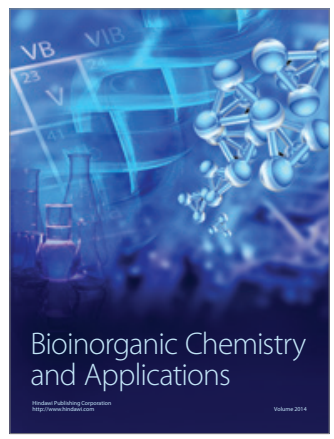

Inorganic Chemistry
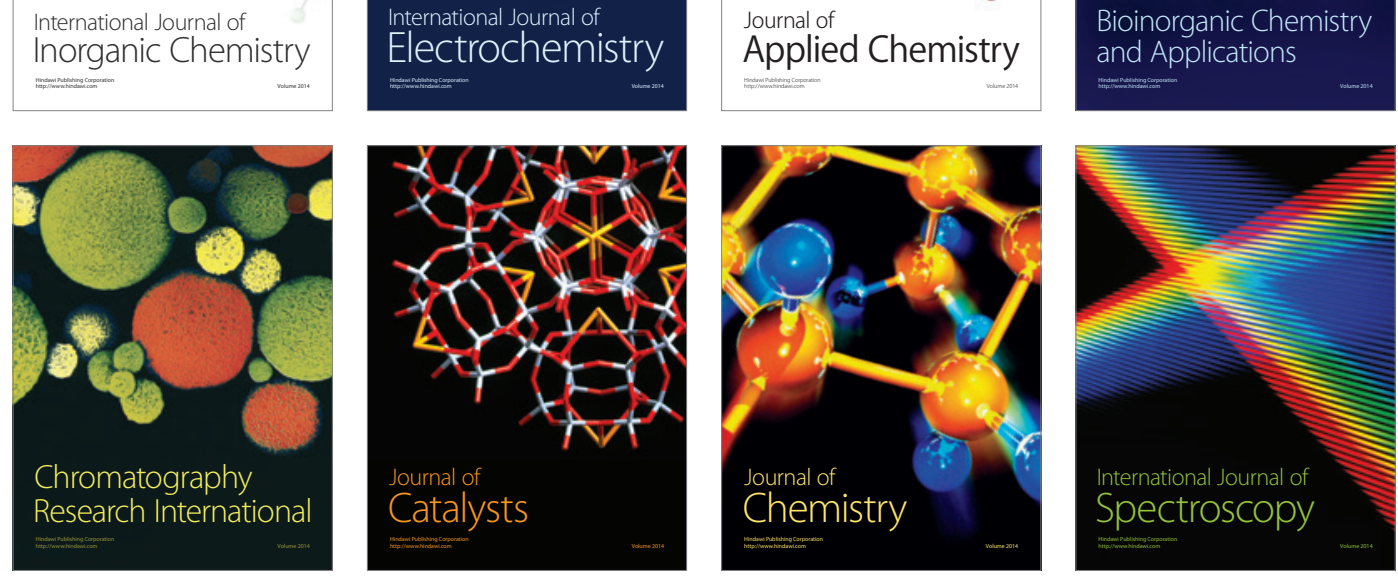